\title{
1. Whither the creative economy? Some reflections on the European case Philip Schlesinger
}

The culture sector suffers from a lack of strategic support and financial investment. The challenge is, thus, to promote and strengthen the contribution of the culture sector to the benefit of the European economy. ${ }^{1}$

\section{INTRODUCTION}

There is now a substantial academic literature that addresses the creative economy. While most of this consists either of advocacy or the application of a set of increasingly orthodox ideas, there is also a growing critical response. ${ }^{2}$ This literature is now available in several languages - although English dominates overwhelmingly - which testifies to the globalisation of the ideas in question. Flew has identified a number of policy variants in recent discussion of the Creative Industries. ${ }^{3}$ Alongside what has emerged in the European Union (EU), distinctive approaches have also been taken in East Asia, China and Australasia. As there are comprehensive reviews of this literature, it would be otiose to repeat thorough work already done by others. ${ }^{4}$ I shall restrict myself to a brief overall comment on the present state of play before considering my case in point, the EU, which illustrates my central contention - that when the creative economy frames the argument this shapes how we might think about the value of culture.

A frequent starting-point point for discussion of the Creative Industries has been the position first outlined by the UK Department for Culture, Media and Sport (DCMS 1998). Aside from proposing individual creativity, skill and talent, wealth and job

1 European Commission, 'Culture: supporting Europe's cultural and creative sectors' < http:// ec.europa.eu/culture/tools/culture-2000_en.htm> accessed 20 August 2015 (original emphasis).

2 See, for instance, E Bustamante (ed.), Industrias creativas: amenazas sobre la cultura digital (Gedisa Editorial 2011); P Bouquillion, B Miège and P Moeglin, L'industrialisation des biens symboliques: les industries créatives en regard des industries culturelles (Presses Universitaires de Grenoble 2013); G Lovink and N Rossiter, MyCreativity Reader: A Critique of Creative Industries (Amsterdam: Institute of Network Cultures 2007); G Raunig, G Ray and U Wuggenig (eds), Critique of Creativity: Precarity, Subjectivity and Resistance in the Creative Industries (MayFly Books 2011); MP Reich, Kultur- und Kreativwirtschaft in Deutschland: Hype oder Zukunfstchance der Stadtentwicklung? (Springer 2013); M Vötsch and R Weiskopf, 'Thank you for your creativity': "Arbeit" und "Kreativität" im Diskurs der creative industries' in R Diaz-Bone and G Krell (eds), Diskursanalytische Perspektiven auf Märkte und Organisationen. Wiesbaden: VS Verlag für Sozialwissenschaften (Springer 2009) 293.

3 T Flew, The Creative Industries: Culture and Policy (Sage Publications 2012).

4 See, for example, Flew (n 3); J O'Connor, The Cultural and Creative Industries: A Literature Review (2nd edn, Creativity, Culture and Education 2010). 
creation, and intellectual property (IP) as the linchpins of its approach, the DCMS designated 13 sectors as 'creative industries'. Now, some two decades later, the strategy of aggregating discrete sectors and thereby creating a distinct policy object has become quite commonplace in many states. It is precisely this approach that has been taken, even if the sectors designated and their descriptions have varied from place to place. In the British case, the 'industries' identified as creative were: advertising, architecture, the art and antiques market, crafts, design, designer fashion, film, interactive leisure software, music, the performing arts, publishing, software and television and radio. ${ }^{5}$ There have been various modifications and refinements to these ideas both within government and in the literature produced by the policy community. That said, it is the apparently simple verities just outlined that have been most readily reproduced and apprehended.

In current critical academic discussion, the 'creative industries' have often been contrasted to the 'cultural industries', which have been described as 'primarily involved in the mass production, circulation and consumption of symbolic texts' ${ }^{6}$ The idea of the cultural industries was previously in wide circulation, having been prominently used by Marxist political economists in the 1980 s as a tool to analyse the composition and workings of the cultural field. Cultural industries policies were also initiated by left-wing governments at national and local levels to harness ameliorative political projects aimed at countering de-industrialisation or to signal the import of new forces of production, distribution and exchange in an 'information society'. An attempt to reclaim this earlier ground is under way. Proponents seek to argue the case for a change of terminology that is also intended to signal an alternative vision of society and the public good. ${ }^{7}$

The dominant view of the Creative Industries, then, has emphasised the economisation of culture, and also increasingly how this is interconnected with the information or digital economy. ${ }^{8}$ This approach has stressed the tradability, exploitation, and commodification of culture. Arguably, in this kind of framework culture is conceived first and foremost as a resource to be exploited. What then follows is the conundrum of how to relate culture to the Creative Industries, as these have usually been defined as distinct. This problem has occasioned a good deal of definitional fancy footwork. A common conceptual strategy has been to produce either lists or visualisations of what are designated 'core' cultural activities and then to identify those that are seen as derivative or secondary modes of exploitation of cultural content. ${ }^{9}$ There is much room for

5 Department for Culture, Media and Sport, 'Creative industries mapping document' (The Stationery Office 1998) 3. See also contribution to this collection by Stapleton and for a different perspective, Isar.

$6 \mathrm{~K}$ Oakley and J O'Connor (eds), The Routledge Companion to the Cultural Industries (Routledge 2015) 10; D Hesmondhalgh, The Cultural Industries (2nd edn, Sage Publications 2007).

7 J O'Connor, 'After the creative industries: why we need a cultural economy' (2016) 47 Platform Papers, Redfern, NSW Currency House.

8 N Garnham, 'From cultural to creative industries: an analysis of the implications of the 'creative industries' approach to arts and media policy making in the United Kingdom' (2005) 11 International Journal of Cultural Policy 15.

9 The Work Foundation, 'Staying ahead: the economic performance of the UK's creative industries' (The Work Foundation 2007); KEA European Affairs, 'The Economy of Culture in Europe. Study prepared for the European Commission' (Directorate-General for Education and Culture, October 2006). 
discussion of where the boundaries of the one or the other may lie. Whether this is at all an interesting question depends on whether or not you embrace the Creative Industries as an organising idea.

The successor term to the Creative Industries is that of the 'creative economy'. Also part and parcel of the prevailing orthodoxy, this lays emphasis on IP and its key role in 'the global battle for comparative advantage'. ${ }^{10}$ The prime case made for taking creativity seriously is that it has an economic dimension and that it should therefore be regarded as 'a substantial component of human capital'. ${ }^{11}$

In what follows, I wish to show how this approach to creative economy thinking and cultural policy intersect in practice. Of course, this kind of analysis can be and has been performed at the level of the state. ${ }^{12}$ However, by contrast the EU is a particularly interesting case because its institutional nexus has to balance the national strategies of the 28 Member States - each with a cultural policy of its own - with the Union's own continuing supranational project, however attenuated that might be at this time of writing. Given different state traditions, a further field of discursive negotiation is in play inside the EU concerning the significance accorded to conceptions of culture per se as opposed to those of a creative economy. ${ }^{13}$

\section{THE CASE OF THE EUROPEAN UNION}

Only in 1992, on ratification of the Treaty on European Union (TEU) at Maastricht did 'culture' emerge as a formal area of competence on the part of the EU, complementary to the role taken in the national management, protection and promotion of culture and identity by Member States. The lodestar statement came in Article 128 of the TEU, subsequently embodied in Article 151 of the Treaty of Amsterdam 1997: 'The Community shall contribute to the flowering of the cultures of the Member States, while respecting their national and regional diversity and at the same time bringing the common cultural heritage to the fore.'

This was a clear statement of the 'unity in diversity' routinely invoked in discussions of EU cultural policy. A multi-level polity, the EU is a site of political compromises, and in the field of culture (as elsewhere) the subsidiary powers of the Member States limit the actions that can be pursued, as well as their scope.

For some, the slogan of 'unity in diversity' 'reflects a kind of 'postmodern communitarianism' designed to overcome the pitfalls of previously essentialist and Eurofederalist

10 J Howkins, The Creative Economy: How People Make Money From Ideas (Penguin 2001) 79.

11 Ibid. 211.

12 D Hesmondhalgh and others, Culture, Economy and Politics: The Case of New Labour (Palgrave MacMillan 2015); P Bouquillion, B Miège and P Moeglin (n 2).

${ }_{13}$ Perhaps this will change. At the CulturalBase project's policy workshop held in Brussels on 31 January 2017, strong indications of a revaluation of the prevalent economism came from EU officials. This turn, still to be confirmed, is related to well-known problems of internal cohesion and the growing perception of external threats both transatlantic and continental, which may combine to make culture as a value system more important than its economic returns. Impending change was also signalled when the author attended the High Level Policy Workshop on 'EU International Cultural Relations' at the European University Institute in Fiesole on 18-19 May 2017. 
concepts of Europe'. ${ }^{14}$ The arrogation of cultural competence is seen as 'the political arm of nation-building at the European level'. ${ }^{15}$ This describes one kind of political impetus that appears to be exhausted. Economic instrumentalism rather than an identity-oriented strategy presently prevails. From the start of the EU's assumption of an explicit cultural competence, views have fluctuated as to how culture and the economy should interrelate. The pursuit of 'single market' considerations - the free movement of goods and workers, the free provision of services, and free movement of capital - has been in tension with the need to recognise and respect the actually existing socio-cultural diversity of the Union. ${ }^{16}$

Currently, 'Creative Europe' is the framework constructed for the field of EU cultural policy between 2014 and 2020. This is a pragmatic label for two streams of activity kept quite distinct until 2014 - cultural programmes and audiovisual programmes. Creative Europe has joined the burgeoning list of creative locales around the globe. The banal label of creativity has authorised the adoption of a seemingly ineluctable trend. Academic works that treat audiovisual policy as a variant of a broader cultural policy still tend to be rare. ${ }^{17}$ Audiovisual trade is a key EU cultural policy arena. ${ }^{18}$ In the digital age, as radical changes in communications rapidly reshape the production, distribution and consumption of cultural contents, established policy frameworks are being reframed so that 'what was formerly known as the audiovisual sector is now understood to be part of the global creative and digital industry'. ${ }^{19}$

In what follows, some key cultural activity undertaken by the EU is outlined. Next, key aspects of audiovisual policy and its relevance to international trade are discussed. This theme encapsulates particularly well how the EU navigates between culture and economy and connects directly to a current major policy, the creation of a Digital Single Market. Finally, the EU's 'cultural and creative industries' (CCIs) policy is considered, underlining the present prevalence of an economistic and market-oriented conception of culture.

\section{CREATIVE EUROPE - THE BRAND}

After adopting its Europe2020 Strategy, and endorsing a European Agenda for Culture, the European Commission set up Creative Europe as successor to two previously separate

14 C Shore 'In uno plures? EU cultural policy and the governance of Europe' (2006) 5 Cultural Analysis 7, 21.

15 Ibid., 19.

16 C Barnett, 'Culture, policy, and subsidiarity in the European Union: from symbolic identity to the governmentalisation of culture' (2001) 20 Political Geography 405.

17 See, for example, I Bondebjerg, EN Redvall and A Higson, 'Introduction: mediated cultural encounters in Europe' in I Bondebjerg and others (eds), European Cinema and Television: Cultural Policy and Everyday Life (Palgrave 2015) 1; A Littoz-Monnet, 'Cultural policy as a contested area' in A Littoz-Monnet (ed.), The European Union and Culture: Between Economic Regulation and European Cultural Policy (Manchester University Press 2007) 1; P Schlesinger, 'From cultural defence to political culture: media, politics and collective identity in the European Union' (1997) 19(3) Media, Culture and Society 369.

18 G Doyle, 'Audiovisual trade and policy' in C Findlay, HK Nordas and G Pasadillo (eds), Trade Policy in Asia: Higher Education and Media Services (World Scientific Publishing 2014) 301.

19 C Crusafon, 'The European audiovisual space: how European media policy has set the pace of its development' in Bondebjerg and others (n 17) 96. 
activity streams - the Culture Programme (2007-13) and the MEDIA Programme (1990-2013).

Craufurd Smith has demonstrated that interventions in culture by the EU and its predecessors predated the TEU, ${ }^{20}$ and has argued that the internal market itself embodies a 'cultural prerequisite' because it is assumed that '[e]conomic integration can lead to more culturally diverse societies, but, to be successful, also requires that those societies be culturally open'. ${ }^{21}$ Consequently, EC law 'posed a challenge not only to the economic but also to the cultural policies of the Member States'. While 'culture' was not defined in EC law, it can and has been used both as a constraint on Community action and as a basis for market intervention, as well as for actions taken under Article 151. The broad scope of the latter 'offers considerable scope for culture to be used instrumentally for political purposes' ${ }^{22}$ the most obvious being the temptation to build a European identity over and beyond the national identities of the Member States. It is not surprising, therefore, that Littoz-Monnet has depicted cultural policy as a 'contested area', where Community intervention has occurred despite the 'strictly defined principle of subsidiarity'. ${ }^{23}$

Culture 2000 was the first attempt to bring coherence to scattered 'actions' pursued since 1992, extending the Commission's focus from high culture to popular culture. While ambitious, the budget was limited and the scope of what might be done continually open to debate. ${ }^{24}$ One line of development was the promotion of culture as a 'catalyst' for creativity, with an emphasis on the economic dimension. ${ }^{25}$

The Culture 2000 programme ran until 2006 'with a budget of $€ 236.4$ million dedicated to promoting a common cultural area, characterised by its cultural diversity and shared cultural heritage'. It covered the performing arts, plastic/visual arts, literature, heritage and cultural history. Its successor, the Culture programme 'ran from 2007-2013 (. .) with a budget of $€ 400$ million to support projects and activities designed to protect and promote cultural diversity and heritage'. ${ }^{26}$

Expenditure on Creative Europe has not quite matched the wide-ranging ambition. The total budget is $€ 1.46 \mathrm{bn}$, of which over $€ 900 \mathrm{~m}$ has been allocated for MEDIA and nearly $€ 500 \mathrm{~m}$ for Culture. ${ }^{27}$ Weighed against the EU's total budget of some $€ 157 \mathrm{bn}$ (in 2017) spending around 1 per cent on culture is small beer indeed.

The EU organizes a bevy of events, prizes and competitions intended to raise awareness of European achievements across borders and, given the need to respect the subsidiarity of the Member States, to engender a wider sense of belonging to a common cultural space. These include the EU Architecture Prize, European Heritage Days, the EU Prix MEDIA,

\footnotetext{
20 R Craufurd Smith, 'Community intervention in the cultural field: continuity or change?' in R Craufurd Smith (ed.), Culture and European Union Law (Oxford University Press 2004).

21 R Craufurd Smith, 'Introduction' in R Craufurd Smith (ed.), Culture and European Union Law (Oxford University Press 2004) 3-4.

22 R Craufurd Smith, 'Article 151 EC and European identity' in Craufurd Smith, ibid., 294.

23 Littoz-Monnet (n 17) 2-3.

24 Craufurd Smith (n 20) 29-30.

25 FAF Langen, 'EU cultural policy 1974-2007' (2010) PhD thesis: University of Glasgow 142-3 <http://theses.gla.ac.uk/2149/> accessed 29 May 2017.

26 European Commission, 'Culture: supporting Europe's cultural and creative sectors' (2015a) <http://ec.europa.eu/culture/tools/culture-2000_en.htm> accessed 20 August 2015.

27 Crusafon (n 19) 97.
} 
the EU Literature Prize, European Border Breakers Awards for popular music and the European Heritage Prize (otherwise known as Europa Nostra).

Best known of the EU's interventions is the more than 30-year-old European Capitals of Culture (ECOC) initiative designed to '[h]ighlight the richness and diversity of cultures in Europe; celebrate the cultural features Europeans share; increase European citizens' sense of belonging to a common cultural area; foster the contribution of culture to the development of cities.' But urban regeneration and a boost to tourism are also part of the package. ${ }^{28}$ Sassatelli's research suggests that ECOC 'is the EU's most direct attempt, both practical and symbolic, to substantiate a "European cultural space" by seeking to engender local connections to the European project. ${ }^{29}$

Creative Europe's second sub-programme succeeded the MEDIA programmes first set up in 1990. The budget for the last free-standing MEDIA programme was $€ 790 \mathrm{~m}$ compared to $€ 900 \mathrm{~m}$ under Creative Europe. ${ }^{30}$ The principal 'activities, projects, and initiatives in the European audiovisual industry' supported by MEDIA are 'training professionals; developing production projects; distributing films and audiovisual programmes; promoting films and audiovisual programmes; supporting film festivals; and promoting the use of new technologies'. ${ }^{31}$ The EU has sought to bolster the audiovisual industry, given its endemic weakness relative to the US.

Originally conceived as distinct from other cultural projects, the MEDIA Programme was a response to deregulation, when public service broadcasters were faced with growing commercial competition throughout the Member States and the accelerating importation of US films and TV series (mostly due to new demand for popular content by private television stations). Furthermore, it addressed the first stage of the coming digital revolution in the form of the so-called 'information superhighway'. ${ }^{32}$ MEDIA was also the legatee of an attempt to devise a cultural and information space. ${ }^{33}$ Now largely forgotten, a pan-European identity politics was linked to the creation of a single audiovisual market, once ascribed a major role by the Commission in promoting recognition of a 'common destiny'. ${ }^{34}$ Successive European Commissions have believed in the 'diffusion' of a common identity-building message through film and television. ${ }^{35}$ And yet, the economy was always firmly inscribed in the cultural project: protection of European

28 European Commission, 'European Capitals of Culture' (2015) <http://ec.europa.eu/programm es/creative-europe/actions/capitals-culture_en.htm> accessed 3 August 2015.

29 M Sassatelli, 'Narratives of European identity' in Bondebjerg and others (n 17) 32.

30 Crusafon (n 19) 97.

31 European Commission, 'Creative Europe' < http://ec.europa.eu/programmes/creative-europe/> accessed 3 August 2015.

32 P Schlesinger and G Doyle, 'Contradictions of economy and culture: the European Union and the Information Society' (1995) 2(1) The European Journal of Cultural Policy 25-42.

33 Commission of the European Communities, 'Television without Frontiers: Green Paper on the establishment of the common market for broadcasting, especially by satellite and cable (COM, 84, 300 final)' (1984) Brussels: CEC 2.

34 P Schlesinger, Media, State and Nation: Political Violence and Collective Identities (Sage Publications 1991).

35 JF Polo, 'L'audiovisuel au service de l'Europe? Les ambiguités de la naissance de la politique audiovisuelle européenne' in P Aldrin, N Hubé, C Ollivier-Yaniv and J-M Utard (eds), Les médiations de l'Europe politique (Presses Universitaires de Strasbourg 2014) 96. 
cultural identity by strengthening film and TV production was simultaneously linked to job-creation at home as well as combatting 'the American challenge' - le défi américain.

The goals have remained largely the same for successive programmes. Creative Europe seeks 'to strengthen the audiovisual sector, increase the circulation of European audiovisual works in and outside the EU, and to strengthen international competitiveness by targeted financial support and encouraging the use of digital technologies' ${ }^{36}$

The outcome of intervention has not been decisive. Some 68 per cent of European cinema admissions are to screenings of US movies and only 25 per cent of admissions are accounted for by European films, ${ }^{37}$ whereas the 'non-national European share of films (the share of all European films outside their own national territory) was only 8 per cent'. ${ }^{38}$ The overwhelming dominance of the box office by the US - due to the large domestic market and profitable investment in audiovisual production, along with the relatively restricted circulation of European movies - has been a longstanding object of EU policy concern. By contrast with the US, Europe's marketplace remains fragmented linguistically and culturally: the EU 'has an annual trade deficit in audiovisual services with the United States of between $€ 6$ billion and $€ 7$ billion and television content accounts for around half of this' ${ }^{39}$ Concern about the market for film has extended to television.

Since 1989, a complementary framework of support has existed to that of the MEDIA programme. The Eurimages ${ }^{40}$ programme, open to the Council of Europe's 47 Member States, was funded at $€ 25$ million in 2016. It supports cinema co-production, theatrical distribution and exhibition. About 50 films annually have secured Eurimages finance. De Vinck and Pauwels have observed that the key issue is not the volume of film production in Europe but 'how this translates into competitiveness and audience reach'. ${ }^{41}$ Performance has been weak because of Europe's cultural and linguistic diversity, uncompetitive levels of investment, and a fragmented market structure and industry still framed by the national boundaries of Member States. The key missing dimension, De Vinck and Pauwels have remarked, is the lack of European demand for European audiovisual products. ${ }^{42}$

Measures taken by the EU and also the Council of Europe have sought both to develop the audiovisual single market and underpin the circulation of European content. The response to the digital challenge by both MEDIA and Eurimages has raised questions about the low budgetary commitment to servicing the needs of producers, distributors and exhibitors, and how best to address the revolution in digital distribution and consumption. The Maastricht understanding of the EU's cultural competence means that policy intervention has been supplementary to national systems of support. Bondebjerg and Redvall wistfully comment that ' $[\mathrm{t}]$ he limited audiovisual European presence on all

36 European Commission, 'Creative Europe' (2015c) <http://ec.europa.eu/programmes/creativeeurope/> accessed 3 August 2015.

37 Crusafon (n 19) 81.

38 Bondebjerg (n 17) 6.

39 Doyle (n 18) 311.

40 Council of Europe, 'Eurimages - European Cinema Support Fund' (COE 2017) <www.coe. int/t/dg4/eurimages/default_en.asp\#> accessed 2 February 2017.

41 S De Vinck and C Pauwels, 'Beyond borders and into the digital era: future-proofing European-level film support schemes' in Bondebjerg and others (n 17) 107.

42 Ibid. 117. 
types of European screens indicate that we are much more national and American in our cinema and television lives than we are European ${ }^{43}$ Bondebjerg has subsequently argued that European TV co-productions, especially those rooted in public service broadcasting, have resulted in increased prime-time circulation of European television drama (not least Scandinavian noir). ${ }^{44}$ Yet this relatively modest counterflow to both the national and American dominance in transnational European television appeals most to elite audiences and is not a major counterweight to box office dominance by the US studios and overthe-top services such as Netflix. ${ }^{45}$

\section{BORDERLESS TELEVISION}

By the 1980s, a conception of a European audiovisual space facilitated by the potential of satellite technology was in vogue. The crossing of national borders by satellite-borne signals required a new legal and regulatory framework, the immediate background to the creation of the Television without Frontiers (TWF) Directive. ${ }^{46}$ Early attempts at creating a Europe-wide TV channel failed but the underlying thinking was a key step towards TWF. Euronews and the loosely integrated Franco-German ARTE are all that now remain of this original ambition. ${ }^{47}$

First adopted in 1989, the TWF Directive came into effect in 1991. Revised in 1997 and again in 2010, it was retitled the Audiovisual Media Services Directive (AVMS) and, at the time of writing, is undergoing further revision. The AVMS's purpose has been to ensure 'the transition from national markets to a common programme production and distribution market, and to guarantee conditions of fair competition'.48 Audiovisual works are described as being 'as much cultural services as they are economic services'. ${ }^{49}$

European works identified in Article 16 of the Directive ${ }^{50}$ include not only those originating in Member States, or those of member states of the Council of Europe signed up to the transborder television agreement, but also works produced or co-produced by countries with which the EC has made agreements, as well as others with which there are bilateral agreements.

Like its predecessor TWF, the AVMS is principally focused on market liberalisation, updated 'to reflect developments in an increasingly technologically convergent media

43 I Bondebjerg and EN Redvall, 'Introduction: mediated cultural encounters in Europe' in I Bondebjerg and others (n 17) 14.

44 I Bondebjerg, 'Transnational Europe: TV-drama, co-production networks and mediated cultural encounters’ (2016) Palgrave Communications (palcoms.2016.34) DOI:10.1057 1-13.

45 Bjondeberg (n 44) 12.

46 Polo (n 35) 106.

47 JK Chalaby, 'Public broadcasters and transnational television: coming to terms with the new media order' in P Iosifides (ed.), Reinventing Public Service Communication: European Broadcasters and Beyond (Palgrave Macmillan 2010); A Hartemann, 'La fabrique de l'Europe aux prise avec les logiques nationales: l'émission Zoom Europa sur ARTE' in Aldrin and others (n 35), 305.

48 Official Journal of the European Union 'Directive 2010/13/EU of the European Parliament and of the Council' of 10 March 2010 L 95/18 15 April 2010, para 2.

49 Ibid., para 5.

50 Ibid. 
environment'. ${ }^{51}$ Much attention has been paid to the 'quota' that requires broadcasters to broadcast a preponderance of European content 'where practicable' for both cultural and economic purposes. Enforcement of the AVMS has been weak, with the quota 'a symbolic rather than substantive provision'. ${ }^{52}$ Neither legally binding nor involving sanctions, arguably it has been without any discernible effect in improving the EU's competitive position vis-à-vis the US. ${ }^{53}$ The EU's regulatory intervention in defence of screening European works by Member States' broadcasters and on-line providers is arguably even less subject to regulation in the transforming non-linear environment. ${ }^{54} \mathrm{~A}$ new legislative proposal amending the Directive was adopted by the European Commission in May 2016. At this time of writing, given divergent views between the Commission and the European Parliament and a lack of consensus in the European Council it is uncertain what final form the Directive will take.

\section{AUDIOVISUAL TRADE}

On an international level, audiovisual policy came to the fore in 1992 - crystallising the EU's policy stance - during the Uruguay Round of negotiations under the General Agreement on Tariffs and Trade ('GATT'). The GATT (1948-94) was a multilateral agreement regulating international trade, focused on eliminating preferences and other barriers. In the GATT, the European Commission undertook negotiations on behalf of the Member States, presenting the European Commission as a collective cultural agent on the world's stage. ${ }^{55}$

The formulation of the so-called 'exception culturelle' was key to the European position on culture taken in the GATT negotiations. The cultural exception centred on preventing cultural goods and services from being treated like any other tradable commodity. During the Uruguay Round, contesting the free market principles espoused by the US, the European Commission sought to defend the EU's film and TV sectors, and the nonmaterial IP rights embodied in the content of specific works.

For the US, audiovisual content was (and is) simply part of the entertainment industry. In France, and the then European Community more generally, audiovisual production was specifically regulated and some of it financed in the national interest. In the Uruguay Round, the US sought to extend free trade principles to services and IP rights. In the succeeding General Agreement on Trade and Services (GATS) and the agreement established under the World Trade Organization (WTO) in 1995, audiovisual trade was excluded from the provisions. However, this position has never been accepted by the US, and remains unresolved ${ }^{56}$ whereas the audiovisual sector is not safe from the WTO's free trade principles. ${ }^{57}$ Trade

51 M Michalis, 'EU broadcasting governance and PSB: between a rock and a hard place' in Iosifides (n 47), 43.

52 Doyle (n 18) 214.

53 Michalis (n 51).

54 Bustamante (n 2); S Regourd, L'exception culturelle (2nd edn, Presses Universitaires de France 2004).

55 Regourd, ibid., 70; Schlesinger (n 17).

56 M Barri, 'Trade versus culture: the policy of cultural exception and the WTO' in K Donders and others (eds), The Palgrave Handbook of European Media Policy (Palgrave Macmillan 2014) 479.

57 Regourd (n 54). 
liberalisation has continued to be pursued at successive WTO summits and, as Susan Sell has tellingly shown, global trade is subject to powerful lobbying by private corporations. ${ }^{58}$

That the WTO negotiations were a mere suspension of hostilities was evident from the talks that led to the Multilateral Agreement on Investment (MAI), published in 1998, with audiovisual services now bundled with other public services. The French delegation argued for a continuing cultural exception and that the 'MAI should allow the signatories to implement policies designed to promote cultural and linguistic diversity and consequently, to protect and promote industries ensuring such diversity. ${ }^{, 59}$ Although the MAI failed, it revealed a continuing determination by the US to change the global rules of the investment game, pushing aside national barriers defended on the basis of a cultural exception.

The demand for a cultural exception by the EU is inherently protectionist whereas the pursuit of the European single market has favoured internal competition and market liberalisation. ${ }^{60}$ Such internal contradictions in the EU's policy stances have been reflected in divergent political views on the implications of the proposed Transatlantic Trade and Investment Partnership (TTIP), whose novelty according to De Ville and Silles-Brügge lay in the pursuit of 'deep liberalisation' of free trade agreements between the EU and the US. ${ }^{61}$ This involved bilateral and highly secret negotiations between the EU and the US, which began in June 2013. ${ }^{62}$ Although the election of Donald Trump to the US presidency in November 2016 effectively put TTIP into cold storage, its very prospect aroused very revealing interest group and civil society reactions across a wide range of fields. These ranged from concern about opening EU markets to Genetically Modified foods to the US corporations seeking the privatisation of health and other public services. Had a treaty been effected this would have covered 40 per cent of global Gross Domestic Product, including all the sectors encompassed in Creative Europe. These negotiations reignited arguments concerning a 'cultural exception'. The respective positions taken in the course of negotiations, therefore, remain of more than historic interest.

The EU's official negotiating stance during the TTIP discussions reaffirmed the importance of cultural diversity and of the CCIs as 'one of the continent's most dynamic sectors, employing some five million people that contributes around 2.6 per cent of the EU's GDP'. ${ }^{63}$ The CCIs officially include performing arts, visual arts, cultural heritage,

58 SK Sell, Private Power, Public Law: The Globalization of Intellectual Property Rights (Cambridge University Press 2003).

59 OECD, 'Negotiating Group on the Multilateral Agreement on Investment (MAI). The Multilateral Agreement on Investment, Draft Consolidated Text. Introduction of an exception clause for cultural industries. DAFFE/MAI(98)T/REV1' (OECD 1998) 127 <www.oecd.org/daf/ mai/pdf/dg1/dg1953e.pdf> accessed 29 May 2017.

${ }_{60}$ Regourd (n 54) 72-3.

61 F De Ville and G Silles-Brügge, TTIP: The Truth about the Transatlantic Trade and Investment Partnership (Polity Press 2016) 5.

62 G Moody, 'TTIP explained: the secretive US-EU Treaty that undermines democracy' (Arstechnica, 7 May 2015a) <http://arstechnica.co.uk/tech-policy/2015/05/ttip-explained-the-secre tive-us-eu-treaty-that-undermines-democracy/> accessed 29 May 2017; G Moody, 'EU arts policies could lead to ISDS lawsuits admits German government' (Arstechnica, 2 June 2015) <http://arstec hnica.co.uk/tech-policy/2015/06/eu-arts-policies-could-lead-to-isds-lawsuits-admits-german-govern ment/> accessed 29 May 2017.

63 European Commission, 'TTIP and culture. Factsheet' (16 July 2014) 1. < http://trade.ec.europa. eu/doclib/docs/2014/july/tradoc_152670.pdf> accessed 21 August 2015. 
film, television and radio, music, book publishing, press, video games, new media, architecture, advertising, graphic and fashion design.

'Cultural diversity' became the successor defensive position to that of the cultural exception. This occurred after the UNESCO General Conference's adoption in October 2005 of the Convention on the Protection and Promotion of the Diversity of Cultural Expressions. This followed 'an international campaign of influence [led by Canada and France] that led to UNESCO's Universal Declaration on Cultural Diversity', the precursor to the Convention. ${ }^{64}$

The EU is obliged to take 'cultural aspects' into account by the Treaty on the Functioning of the European Union, Article 167. ${ }^{65}$ In line with this, the 2005 UNESCO Convention was presented in TTIP negotiations on trade v culture as legally binding the EU 'to promote cultural diversity'. The EU intended the TTIP preamble to underline this commitment. ${ }^{66}$ While the 'traditional exclusion' of the audiovisual sector from foreign competition was noted, the European Commission commented that 'the so-called 'cultural exception' has no legal status under EU law [which] (. . .) refers to the concept of 'promotion of cultural diversity". ${ }^{67}$

To value the particularity of cultural diversity is to raise questions about the 'neutrality' of the market and the state. ${ }^{68}$ In line with this, the UNESCO Convention has been interpreted as being a 'cultural counterbalance to the WTO', ${ }^{69}$ bringing a new principle into international public law, namely that of a government's right to promote the diversity of cultural expressions. The term 'expression' shifted the focus from contentious definitions of culture to 'the markets where it is represented'. ${ }^{70}$ The Convention, as Regourd has commented, does not override the treaty obligations of states. ${ }^{71}$ Consequently, how it might affect negotiations over cultural markets would depend less on the acuity of the negotiators than on the actual balance of forces, not least the scale and economic power of the negotiating parties. The UNESCO Convention could not be an effective protection against moves pursued by the US under Transatlantic Economic Council (TEC) negotiations to distinguish between traditional audiovisual and new digital services as these 'might go beyond infrastructure issues and also impact on content industries', as well as diversity and plurality in the EU. ${ }^{72}$

Although the special status of the audiovisual sector for the EU has been underlined, other cultural sectors not similarly singled out (such as publishing and classical music)

64 YR Isar, 'Widening local development pathways: transformative visions of cultural economy' in Oakley and O'Connor (n 6) 479.

65 Treaty on the Functioning of the European Union (2012) <http://eur-lex.europa.eu/ legalcontent/FR/TXT/HTML/?uri=CELEX:12012M/TXT\&from=EN> accessed 24 August 2015.

66 European Commission (n 63) 2-3.

67 Ibid., 4.

68 P Meyer-Bisch, 'La valorisation de la diversité et des droits culturels' (2008) 51 Hermès 59-64.

69 CB Graber, 'The new UNESCO Convention on cultural diversity: a counterbalance to the WTO?' (2006) 9(3) Journal of International Economic Law 553, 559.

70 Ibid., 558.

71 Regourd (n 54) 123-4.

72 L Richieri Hanania and H Ruíz Fabri, 'European media policy and cultural diversity at the international level: the EU's role in fostering the implementation of the 2005 UNESCO Convention' in Donders and others (n 56) 493, 499. 
registered their concern, as did those supporting the general principle of subsidies for culture. Audiovisual interests feared that US interests using TTIP, not least the aggregators and video-on-demand suppliers, might circumvent existing protections and focus particularly on the market opportunities afforded by new digital delivery systems ${ }^{73}$ or attack the fairness of national subsidies to film producers. ${ }^{74}$ Writing in 2017 , at the explosive start of the Trump presidency, it seems evident that the stakes have risen in how global trade is to be conducted. TTIP may be in cold storage but the concerns expressed in debate have not become irrelevant.

\section{THE DIGITAL SINGLE MARKET}

Mario Monti, economist, technocrat and sometime Italian prime minister, wrote a report on completing the 'single market' at the behest of the then European Commission President, José Manuel Barroso. This acknowledged that 'the single market is less popular than ever, yet it is more needed than ever'. The central political purpose was stated in these terms: 'the single market, if it is strengthened to resist nationalism and adjourned (sic) to be more consistent with other concerns and policy objectives, is the best response to globalization' ${ }^{75}$

The EU, Monti argued, faced a number of key obstacles: 'the fragmentation of online markets, ill-adapted IP legislation, the lack of trust and interoperability, the lack of high-speed transmission infrastructure and the lack of digital skills' ${ }^{76}$ Far-reaching recommendations were made 'for creating a seamless regulatory space for electronic communications' to 'end the fragmentation of EU consumer legislation' and 'for an EU copyright law, including an EU framework for copyright clearance and management', as well as 'a legal framework for EU-wide online broadcasting'. ${ }^{77}$

At the start of his mandate, in July 2014, the new European Commission President JeanClaude Juncker made the DSM his second priority. The Commission's Communication on A Digital Single Market, published in May 2015, made it clear that the creative economy was seen as deeply intertwined with the future of the digital economy, being seen as a major force for change. ${ }^{78}$

73 H Aylett, Tipping point (Sight\&Sound 2015) 57; FERA, 'The cultural exception vs TTIP' (2013) <www.filmdirectors.eu/wp-content/uploads/2013/07/FERA-Newsletter-July-2013_English. pdf> accessed 26 August 2015.

74 A Produzenten, 'Karel de Gucht über TTIP: "Film und Fernsehen nicht Gegenstand des Verhandlungsmandats"' (Produzenten Allianz, 18 June 2014). <www.produzentenallianz.de/presse schau/einzelansicht/article/karel-de-gucht-ueber-ttip-film-und-fernsehen-nicht-gegenstand-des-verh andlungsmandats.html > accessed 22 August 2015.

75 M Monti, 'A new strategy for the single market: at the service of Europe's economy and society.' (9 May 2010) A report to the President of the European Commission, José Manuel Barroso 20-21.

76 Ibid., 44.

77 Ibid., 46.

78 European Commission, 'Communication from the Commission to the European Parliament, the Council, the European Economic and Social Committee and the Committee of the Regions' (2015d) A Digital Single Market Strategy for Europe $\{\operatorname{SWD}(2015) 100$ final $\}$. Brussels, 6.5.2015 COM(2015) 192 final. <http://eur-lex.europa.eu/legal-content/EN/TXT/PDF/?uri=CELEX:52015 DC0192\&from $=\mathrm{EN}>$ accessed 24 August 2015. 
An account such as this one is bound to be overtaken by events but the general direction of travel is fairly clear. The European Commission has announced that ' 33 sectors of the EU economy are considered copyright-intensive, accounting directly for 7 million jobs or 3 per cent of employment in the EU'. For the European Commission, ${ }^{79}$ the DSM is situated in the wider context of the 'four freedoms' of the internal market - the free circulation of goods, services, persons, and capital. The DSM's underlying rationale is to reduce barriers to e-commerce but it also has a truly major focus on culture and media.

Increasingly, the connectivity agenda (high-speed internet, effective and affordable EU-wide telephony, access to services and commerce) and the cultural agenda are intertwined. Here, the main areas of the DSM pertinent to the present analysis are briefly outlined.

1. Regulation of the cross-border 'portability' of on-line content is key to the developing digital audiovisual market. This would establish the same access conditions for subscribers to a service, as they would have in their home Member State.

2. Addressing exceptions to copyright rules for educational purposes, of major significance for the unhindered circulation of cultural works in a defined context of use.

3. Remuneration of copyright protected works. This is of considerable relevance for disputes between newspaper publishers and aggregators and social media sites.

4. IP rights enforcement in relation to infringements is relevant to the returns to rights holders and connected to the viability of cultural producers.

5. Effective and uniform application of copyright legislation across the EU, which is evidently a long-term aspiration that depends on the harmonisation of diverse legal systems.

6. Revision of the AVMS Directive that may recast broadcasting regulation to bring video-on-demand and over-the-top platforms into a common framework.

\section{CONCLUDING REMARKS}

Creative Europe's tagline is 'supporting Europe's cultural and creative sectors' (CCS). There is a nuance in the designation of CCS, which avoids talking solely about the Creative Industries and carefully acknowledges the emphasis placed on culture in key Member States. This composite profile expresses a long-standing tension at the heart of the EU's support programmes - between the valorisation of culture as a common good and possible route to building a transnational identity and citizenship over time, and an emphasis on the Creative Industries as a potential counterweight to decline due to a longrunning and still unresolved economic crisis. The inherent ambiguity of the European project has been inscribed in policy and implementation from the very start. Creative Europe's goals are intended both to address the challenge of globalisation and to enable the sectors concerned to achieve their economic potential.

79 European Commission, 'A digital single market for Europe' (2016) < https://ec.europa.eu/ priorities/sites/beta-political/files/2-years-on-dsm_en_0.pdf $>$ accessed 2 February 2017. For consideration of some developments, see the contribution to this collection by Reda. 


\section{Research handbook on IP and creative industries}

Two telling signs of orthodox thinking occur first, when given perspectives and stock phrases become de rigueur and second, when a particular conceptual framework is reproduced without taking critical distance. These two conditions have increasingly characterised the European cultural policy scene for the past decade. For instance, such developments may be tracked by observing how policy ideas are launched and reworked in reports commissioned for the EU to provide ammunition for policy developments, ${ }^{80}$ bringing into focus the wider matter of how expertise is deployed in the European space. ${ }^{81}$ A major contemporary reference point at a global level has been the UN's Creative Economy report, ${ }^{82}$ and its successor versions in 2010 and 2013.

Not all EU Member States have taken up the creative economy cause with equal enthusiasm. Nevertheless, by degrees the European Commission was won over to taking it seriously. The CCIs are at the heart of the European Agenda for Culture, part of the framework of the EU's Lisbon Strategy for jobs and growth, originally set out in March 2000 ${ }^{83}$ In May 2007, the European Council endorsed the role that the CCIs might play in supporting the Lisbon Strategy and in April 2008, the European Parliament welcomed the Council and Commission's recognition of the importance of culture and creativity for the European project. By 2010, a turning point was reached when the creative economy became part of the European Commission's conventional wisdom, ${ }^{84}$ setting the scene for the Digital Single Market. ${ }^{85}$

From the very start, EU cultural policy has been harnessed to economic purposes and, at times, to the politics of identity, citizenship and community-building. The EU is boxed

80 There has a been a steady flow of subsequent reports. The main shift in recent years has been to place an increased emphasis on the measurement of the creative economy (for example, KEA 2012). See KEA European Affairs, 'The Economy of Culture in Europe. Study prepared for the European Commission' (Directorate-General for Education and Culture, October 2006); KEA European Affairs, 'The Impact of Culture on Creativity. A Study prepared for the European Commission' (Directorate-General for Education and Culture, June 2009) <Ec.europa.eu/culture/ library/studies/cultural-economy_en.pdf $>$ accessed 20 August 2015.

81 I have analysed this process in the formation of creative economy thinking in the UK. See P Schlesinger, 'Creativity: from discourse to doctrine?' (2007) 48(3) Screen 377-87; P Schlesinger, 'Creativity and the experts: New Labour, think tanks and the policy process' (2009) 14(3) International Journal of Press Politics 3-20. See also C Radaelli, 'The public policy of the European Union: whither the politics of expertise' (1999) 6(5) Journal of European Public Policy 757.

82 UNCTAD, 'Creative economy report' (UNCTAD 2008).

83 In the two paragraphs above, I have drawn on P Schlesinger, M Selfe and E Munro, Curators of Cultural Enterprise: A Critical Analysis of a Creative Business Intermediary (Palgrave Macmillan 2015), 15.

84 The European Forum on Cultural Industries, 'Tracing a growth path for the creative economy', A Vassiliou, speech 10/140 delivered on 29-30 March 2010 in Barcelona <http://europa.eu/rapid/ press-release_SPEECH-10-140_en.htm> accessed 29 May 2017; European Commission, 'Green Paper: unlocking the potential of cultural and creative industries' Brussels, 27.4.2010 COM(2010) 183 final <http://eur-lex.europa.eu/legal-content/EN/TXT/PDF/?uri=CELEX:52010DC0183\&fro $\mathrm{m}=\mathrm{EN}>$ accessed 21 August 2015.

85 The creative policy turn has not produced complete uniformity of thinking inside the EU. Nevertheless, it has impacted on the terms in which culture is thought about in policy-making circles. See D Puchta and others, The Berlin Creative Industries: An Empirical Analysis of Future Key Industries (Gabler Verlag 2010); P Schlesinger, 'The creative economy: invention of a global orthodoxy' (2017) 30(1) Innovation: The European Journal of Social Science Research 73. 
in between the distinctive policies of the Member States and the European institutions' supranational logic. It is this complex dynamic that makes for such a complex and unique case. In the context of international trade, the pursuit of cultural policy has required a shift from arguing for a cultural exception to embracing the cultural diversity of expressions as a legitimation. This latter move has weakened the EU's defences against le défi américain.

Presently, the now 20-year-old discourse on 'creativity' is everywhere increasingly interconnected to the current fixation on the digital economy. How the DSM strategy is pursued, not least in respect of IP rights and the digital distribution of cultural content, will be of major significance for the future of the EU as a cultural actor.

\section{ACKNOWLEDGEMENTS}

This chapter draws on work undertaken under the auspices of the CulturalBase project, funded by the European Commission's Horizon2020 Programme. Various parts of this account have been discussed at CulturalBase events in Barcelona (2015), Florence (2016) and Brussels (2017). My thanks to Professors Peter Golding and Ib Bondebjerg for their incisive comments on an earlier version of this piece, although I doubt I have done justice to their critical views. 